\title{
Effects of Feed Delivery Time on Feed Intake, Milk Production, and Blood Metabolites of Dairy Cows
}

\author{
A. Nikkhah, ${ }^{\star} †$ C. J. Furedi, $\ddagger$ A. D. Kennedy, $\ddagger$ G. H. Crow, $\ddagger$ and J. C. Plaizier $\ddagger^{1}$ \\ *Department of Animal Sciences, University of Illinois, Urbana 61801 \\ †Department of Animal Sciences, Zanjan University, Zanjan, Iran \\ łDepartment of Animal Science, University of Manitoba, Winnipeg, Manitoba, Canada R3T 2N2
}

\section{ABSTRACT}

The objective of the study was to determine the effects of feed delivery time and its interactions with dietary concentrate inclusion and parity on milk production and on 24-h averages and patterns of feed intake and blood metabolites. Four multiparous and 4 primiparous lactating Holstein cows were used in a $4 \times 4$ Latin square design with a $2 \times 2$ factorial arrangement of treatments. Experimental periods included $14 \mathrm{~d}$ of adaptation and $7 \mathrm{~d}$ of sampling. A higher concentrate diet with a forage:concentrate ratio (dry matter basis) of 38:62 or a lower-concentrate diet with a forage:concentrate ratio of 51:49 was delivered at either 0900 or $2100 \mathrm{~h}$. During sampling periods, daily feed intakes, as well as feed intakes during 3-h intervals relative to feed delivery, were determined. During 2 nonconsecutive days of the sampling period, jugular blood was sampled every $2 \mathrm{~h}$. Average temperature and relative humidity in the experimental facility were $20.4^{\circ} \mathrm{C}$ and $68.1 \%$, and the maximum daily air temperature did not exceed $25^{\circ} \mathrm{C}$. This data does not suggest that cows were heatstressed. Changing feed delivery time from 0900 to $2100 \mathrm{~h}$ increased the amount of feed consumed within $3 \mathrm{~h}$ after feeding from 27 to $37 \%$ of total daily intake but did not affect daily dry matter intake. The cows fed at $2100 \mathrm{~h}$ had lower blood glucose at $2 \mathrm{~h}$ after feeding but greater blood lactate and B-hydroxybutyrate acid at 2 and $4 \mathrm{~h}$ after feeding than cows fed at $0900 \mathrm{~h}$. These effects of feed delivery time on the 24-h patterns in blood metabolites may be caused by the greater feed intake during the $3 \mathrm{~h}$ after feed delivery of the cows fed at $2100 \mathrm{~h}$. Daily averages of glucose, urea, lactate, and B-hydroxybutyrate acid and nonesterified fatty acids in peripheral blood were not affected by time of feeding. The change in feed delivery time did not affect milk yield and milk protein but increased milk fat percentage from 2.5 to $2.9 \%$ and milk fat yield from 0.98 to

Received February 4, 2008

Accepted July 18, 2008.

${ }^{1}$ Corresponding author: plaizier@ms.umanitoba.ca
$1.20 \mathrm{~kg} / \mathrm{d}$ in multiparous cows, without affecting milk fat in primiparous cows. The interactions between diet and time of feeding on daily feed intake, milk production, and blood metabolites were not significant. The effects of the time of feed delivery on the 24-h patterns in blood metabolites suggest that this time may affect peripheral nutrient availability. Results of this study suggest beneficial effects of feeding at $2100 \mathrm{~h}$ instead of at $0900 \mathrm{~h}$ on milk fat production of lactating cows, but parity appears to mediate this effect.

Key words: feed delivery time, concentrate level, feed intake, milk production

\section{INTRODUCTION}

Evening feeding, instead of morning feeding, has been shown to attenuate heat stress and improve feed efficiency and lactation persistency in lactating cows (Aharoni et al., 2005) and improve growth of cattle during the winter (Kennedy et al., 2004). The effects of evening feeding in cows that were not heat-stressed or cold-stressed have not been well researched, but Robinson et al. (1997) found that rumen digestion and milk fat yield were increased in cows that received a protein meal at $0030 \mathrm{~h}$ compared with cows that received this meal at $0830 \mathrm{~h}$.

The delivery of fresh feed stimulates eating and affects diurnal patterns of eating in lactating cows (Phillips and Rind, 2001; DeVries et al., 2003). Changes in feed delivery time will, therefore, alter feeding behavior and postfeeding patterns of rumen $\mathrm{pH}$, VFA, and ammonia (Robinson et al., 1997, 2002). Altering 24-h patterns in rumen fermentation and intestinal nutrient delivery will, consequently, affect the hepatic release of metabolites and alter the 24-h patterns of these metabolites in peripheral blood (Sutton et al., 1988; Blum et al., 2000; Plaizier et al., 2005). These changes in the 24-h patterns of blood metabolites could affect the utilization of nutrients, because the concentrations and actions of metabolic hormones that affect nutrient utilization can vary throughout the day, independently from when feed is delivered (Vasilatos and Wangsness, 
Table 1. Ingredient, nutrient, and physical composition of the experimental diets and forages ${ }^{1}$

\begin{tabular}{|c|c|c|c|c|}
\hline \multirow[b]{2}{*}{ Item } & \multicolumn{2}{|c|}{ Forage } & \multicolumn{2}{|c|}{ Diet $^{2}$} \\
\hline & Alfalfa silage & Corn silage & $\mathrm{HC}$ & $\mathrm{LC}$ \\
\hline \multicolumn{5}{|l|}{ Diet ingredients, $\%$ of DM } \\
\hline Alfalfa silage & - & - & 15.9 & 21.0 \\
\hline Corn silage & - & - & 22.7 & 29.7 \\
\hline Energy supplement & - & - & 49.9 & 37.2 \\
\hline Protein supplement & - & - & 11.6 & 12.2 \\
\hline Forage:concentrate ratio & - & - & $38: 62$ & $51: 49$ \\
\hline \multicolumn{5}{|l|}{ Nutrient composition $^{3}$} \\
\hline DM, \% & $34.8(1.9)$ & $44.0(1.1)$ & $63.5(0.79)$ & $55.9(0.92)$ \\
\hline $\mathrm{CP}, \%$ of $\mathrm{DM}$ & $18.2(2.1)$ & $7.42(0.6)$ & $18.1(0.3)$ & $17.3(0.58)$ \\
\hline $\mathrm{NFC}^{4}, \%$ of DM & $21.0(5.6)$ & $37.6(3.5)$ & $39.7(1.34)$ & $35.9(2.5)$ \\
\hline NDF, $\%$ of DM & $47.1(7.0)$ & $47.4(4.2)$ & $28.6(0.75)$ & $33.8(2.6)$ \\
\hline $\mathrm{ADF}, \%$ of $\mathrm{DM}$ & $37.8(4.4)$ & $26.1(1.6)$ & $15.1(0.25)$ & $19.4(0.78)$ \\
\hline Ether extract, \% of DM & $2.9(0.16)$ & $2.3(0.35)$ & $5.9(0.17)$ & $5.3(0.21)$ \\
\hline Ash, \% of DM & $10.7(1.1)$ & $5.2(0.54)$ & $7.8(0.37)$ & $7.8(0.37)$ \\
\hline $\mathrm{Ca}, \%$ of $\mathrm{DM}$ & $1.36(0.33)$ & $0.27(0.04)$ & $1.09(0.1)$ & $1.1(0.17)$ \\
\hline $\mathrm{P}, \%$ of $\mathrm{DM}$ & $0.29(0.06)$ & $0.17(0.02)$ & $0.58(0.1)$ & $0.51(0.1)$ \\
\hline $\mathrm{K}, \%$ of $\mathrm{DM}$ & $2.87(0.39)$ & $1.19(0.07)$ & $1.22(0.04)$ & $1.03(0.03)$ \\
\hline $\mathrm{Mg}, \%$ of $\mathrm{DM}$ & $0.38(0.06)$ & $0.28(0.02)$ & $0.32(0.01)$ & $0.32(0.02)$ \\
\hline $\mathrm{Na}, \%$ of $\mathrm{DM}$ & $0.04(0.01)$ & $<0.01$ & $0.39(0.03)$ & $0.37(0.03)$ \\
\hline \multicolumn{5}{|l|}{ PSPS distributions ${ }^{5}$} \\
\hline Top screen $(19 \mathrm{~mm})$ & $17.2(2.5)$ & $6.4(1.6)$ & $3.7(0.4)$ & $4.0(0.7)$ \\
\hline Second screen $(8 \mathrm{~mm})$ & $46.2(4.4)$ & $56.5(2.4)$ & $34.3(2.0)$ & $40.5(1.4)$ \\
\hline Third screen $(1.18 \mathrm{~mm})$ & $33.8(2.4)$ & $33.9(2.3)$ & $54.1(1.9)$ & $48.0(1.7$ \\
\hline Bottom pan & $2.8(1.1)$ & $3.2(0.4)$ & $7.8(0.2)$ & $6.6(0.3)$ \\
\hline
\end{tabular}

${ }^{1}$ Standard deviations are within parentheses.

${ }^{2} \mathrm{HC}=$ higher concentrate; $\mathrm{LC}=$ lower concentrate.

${ }^{3} \mathrm{n}=4$ for each forage.

${ }^{4} \mathrm{NFC}=100-(\mathrm{NDF} \%+\mathrm{CP} \%+\mathrm{EE} \%+\mathrm{Ash} \%)$

${ }^{5}$ Penn State Particle Separator distributions.

1981; Sehgal, 2004). We, therefore, hypothesize that nutrient utilization differs between morning- and evening-fed cows. The objectives of the current study were to determine the effects of feed delivery time (0900 vs. $2100 \mathrm{~h}$ ), and its interactions with dietary concentrate inclusion and parity, on milk production and on 24 -h averages and patterns of feed intake and blood metabolites.

\section{MATERIALS AND METHODS}

\section{Experimental Design and Cow Management}

Four multiparous and 4 primiparous Holstein cows were used in a double $4 \times 4$ Latin square design. Average BW, BCS (1 to 5 scale), and DIM at the beginning of the experiment were (mean $\pm \mathrm{SD}) 652 \pm 14 \mathrm{~kg}, 2.87$ \pm 0.14 , and $83 \pm 22 \mathrm{~d}$, respectively, for the multiparous cows and $667 \pm 11 \mathrm{~kg}, 3.19 \pm 0.66$, and $81 \pm 23$ $\mathrm{d}$, respectively, for the primiparous cows. The experiment consisted of four 21-d periods. Each period had $14 \mathrm{~d}$ of adaptation followed by $7 \mathrm{~d}$ of data collection. Cows were housed indoors in individual tie stalls in the Metabolism Unit of the Glenlea Research Station, University of Manitoba. All animals had unlimited ac- cess to fresh water. The experiment was conducted for $12 \mathrm{wk}$ starting May 1, 2004. The average air temperature and relative humidity in the experimental facility were $20.4^{\circ} \mathrm{C}$ and $68.1 \%$, respectively. The maximum air temperature of the metabolism unit did not exceed $25^{\circ} \mathrm{C}$ at any time during the study. Cows were cared for according to the guidelines of the Canadian Council on Animal Care (CCAC, 1993). Lights were turned on at $0345 \mathrm{~h}$ and turned off at $2230 \mathrm{~h}$.

Treatments included feeding either a higher concentrate (HC) diet with a forage:concentrate ratio of 38:62 or a lower concentrate (LC) diet with a forage:concentrate ratio of 51:49, either at 0900 or at $2100 \mathrm{~h}$ (Tables 1 and 2). Diets were fed as TMR, which were prepared daily before $0900 \mathrm{~h}$ using a Data Ranger Mixer (American Calan, Northwood, NH) with a Weigh Tronix head (model 1000, American Calan). Cows were fed ad libitum allowing for about 5 to $10 \%$ orts.

\section{Feed Intake and Feed Analyses}

During the collection periods, the amounts of TMR offered and refused were recorded daily for each cow. Feed intakes during 3-h intervals relative to feed delivery were determined by continuously weighing the 
Table 2. Ingredient compositions of energy and protein supplements (\% of DM)

\begin{tabular}{lcc}
\hline Ingredient & Energy supplement & Protein supplement \\
\hline Rolled barley & 54.0 & - \\
Luprosil salt (calcium propionate) $^{1}$ & 0.2 & - \\
Protein pellet $^{1}$ & 1.8 & - \\
Dairy supplement $^{2}$ & 40.0 & 42.0 \\
Tallow (feed grade rendered fat) $_{\text {Dried distillers grain }}$ & 4.0 & 7.0 \\
Fish meal & - & 22.5 \\
Canola meal & - & 20.0 \\
Soybean meal & - & 3.2 \\
Beet molasses & - & 0.3 \\
Niacin (vitamin B3) & - & 5.0 \\
Sodium bicarbonate & - &
\end{tabular}

${ }^{1}$ Protein pellets contain $46.1 \%$ soybean meal, $2.6 \%$ wheat shorts, $40.0 \%$ canola meal, $5.0 \%$ oat hulls, $0.3 \%$ pellet binder, $1.0 \%$ cane molasses, and $5.0 \%$ corn gluten meal.

${ }^{2}$ Dairy supplement contains $0.13 \%$ vitamin ADE premix (vitamin A, 16,800 IU/kg; vitamin D, 2,215 IU/kg; vitamin E, $75 \mathrm{IU} / \mathrm{kg}$, DM basis), 0.13\% trace mineral premix, 2.6\% soybean meal, $0.06 \%$ selenium, $39.1 \%$ wheat shorts, $5.0 \%$ distillers grain, $17.5 \%$ canola meal, $15.0 \%$ ground wheat, $1.7 \%$ dicalcium phosphate, $1.6 \%$ salt, $2.0 \%$ Dynamate (Pitman Moore Inc., Mundelein, IL), 0.3\% pellet binder, $1.0 \%$ cane molasses, 3.7\% calcium carbonate, and $10.0 \%$ corn gluten meal.

feed in the mangers using a data acquisition system (model 4000, GrowSafe Systems, Airdrie, Alberta, Canada) as described by Bhandari et al. (2007). Diet samples were collected daily and pooled for each collection period. Individual cow ort samples were obtained daily during the collection periods and pooled by weight and period. The DM content of pooled diet and orts samples was determined by drying at $60^{\circ} \mathrm{C}$ for 48 $\mathrm{h}$. Dried feed samples were ground using a Wiley mill through a 1-mm screen (Thomas-Wiley, Philadelphia, PA) and were stored at $-20^{\circ} \mathrm{C}$ until analyzed. Before subsequent analysis, analytical DM was determined (method 934.01; AOAC, 1990). All feed samples were analyzed for $\mathrm{CP}$ using the $\mathrm{CuSO}_{4}-\mathrm{TiO}_{2}$ mixed catalyst Kjeldahl procedure (method 988.05; AOAC, 1990), for NDF using a-amylase (A3306, Sigma Chemical Co., St. Louis, MO) and sodium sulfite and corrected for ash concentration adapted for Ankom 200 Fiber Analyzer (Ankom Technology, Fairport, NY) as described by Bhandari et al. (2007), for ADF (method 973.18; AOAC, 1990), for ether extract (method 920.39; AOAC, 1990), and for ash (method 942.05; AOAC, 1990). Calcium, P, $\mathrm{K}, \mathrm{Mg}$, and $\mathrm{Na}$ were measured by inductively coupled plasma emission spectroscopy (method 968.08; AOAC, 1990) using an Atom Scan 25 Plasma Spectrometer (Thermo Jarrell Ash Corp., Grand Junction, CO) after acid digestion.

The Penn State Particle Separator (Kononoff et al., 2003) was used to determine particle size distribution of all TMR and orts samples before drying (Bhandari et al., 2007). The percentage of coarse particles in the orts was determined as the proportion of the orts retained by the 8 - and $19-\mathrm{mm}$ screens of the Penn State Particle Separator.

\section{Milking and Milk Analysis}

Cows were milked twice daily at 0400 and $1600 \mathrm{~h}$ in their stalls, and milk yields were determined using Tru Test regulation meters (Westfalia Surge, Mississauga, Ontario, Canada). Milk samples were collected into 50-mL vials for each cow from 6 consecutive milkings during collection periods, preserved with 2-bromo-2nitropropane- 1,3 diol, and stored at $4^{\circ} \mathrm{C}$. Samples were analyzed for milk components at the laboratory of Dairy Farmers of Manitoba (Winnipeg, Manitoba, Canada) by near infrared using the Milk-o-Scan 303AB (Foss Electric, Hillerød, Denmark) as described by Bhandari et al. (2007).

\section{Blood Analyses}

Blood samples were collected through jugular catheters every $2 \mathrm{~h}$ during the second and the fourth day of each sampling period. Blood sample collection started at $0900 \mathrm{~h}$ and ended at $0900 \mathrm{~h}$ of the subsequent day. Immediately after collection, blood samples were transferred into heparinized Vacutainer tubes (Becton Dickinson, Franklin Lakes, NJ), put immediately on ice, and centrifuged at $3,000 \times g$ for $20 \mathrm{~min}$ at $4^{\circ} \mathrm{C}$ to harvest the plasma. The plasma was immediately frozen at $-20^{\circ} \mathrm{C}$ until analysis. A BHBA reagent (Procedure No. 310-UV, Sigma Diagnostics, St. Louis, MO) and a NEFA kit (Randox Laboratories, Ardmore, UK) were used to measure plasma BHBA and NEFA concentrations using a BM/Hitachi 911 analyzer (Boehringer Mannheim, Mannheim, Germany) as described by Plaizier et al. (2005). Plasma concentrations of glucose, lactate, and urea were determined using an automatic 
Table 3. Effects of diet composition, time of feed delivery (TF, 0900 or $2100 \mathrm{~h}$ ), and parity [primiparous (1) or multiparous ( $\geq 2)$ ] on feed intake, physical composition of orts, and milk production of lactating dairy cows

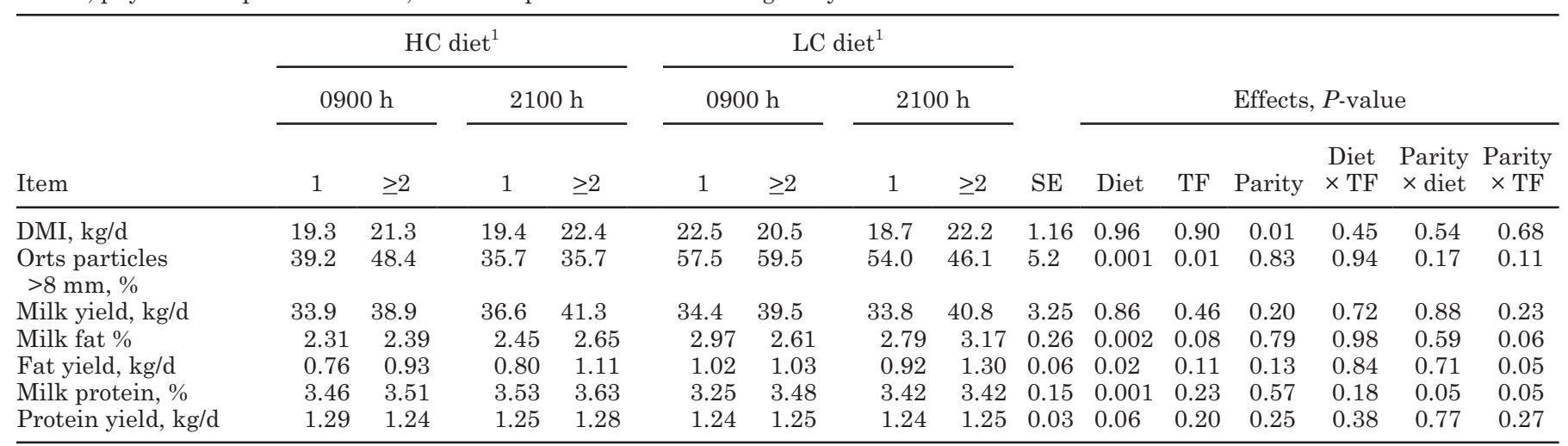

${ }^{1} \mathrm{HC}=$ higher concentrate (forage:concentrate $\left.=38: 62\right) ; \mathrm{LC}=$ lower concentrate (forage:concentrate $=51: 49$ ).

analyzer (Stat Profile Critical Xpress, Nova Biomedical, Waltham, MA) equipped with enzymatic sensors as described by Bhandari et al. (2007).

\section{Statistical Analyses}

An ANOVA of the data on DMI, particle size distribution of orts, and milk production was carried out using the MIXED procedure of SAS (SAS Institute, 2003). Fixed effects included the time of feed delivery, concentrate level, concentrate level $\times$ time of feed delivery, parity, and 2- and 3-way interactions with parity. To compare the effects of milking and the interactions of milking with diet and milking with time of feed delivery, milking was included in the model as a fixed effect. The effects of cow within parity and period were considered random.

Analyses of variance of blood metabolite data during each 24-h period and of the proportions of the daily feed intake consumed within 3 -h periods relative to feed delivery time were conducted using the SAS MIXED procedure (SAS Institute, 2003) for the analysis of animal experiments with repeated measures as described by Plaizier et al. (2005). Hour after feeding was the repeated factor, and cow was the subject. The effects of concentrate level, time of feed delivery, parity, hour, and their 2-, 3-, and 4-way interactions were considered fixed. Random effects included period, cow within parity, day of sampling within period, and greater-level interactions involving these terms. To alleviate heterogeneity of variance of residuals, data were transformed using Box-Cox algorithms (SAS Institute, 2003).

The PDIFF option of SAS (SAS Institute, 2003) was used to separate the least squares means. Residuals were tested for normality of distribution and homogeneity of variance. Fixed effects were declared significant at $P \leq 0.05$, and trends were discussed at $P \leq 0.10$.
Standard errors presented were for the differences among least squares means.

\section{RESULTS AND DISCUSSION}

\section{Feed Intake and Feeding Behavior}

Time of feeding, diet, and their interaction did not affect daily DMI (Table 3 ). Primiparous cows had lower $(P=0.01)$ daily DMI than multiparous cows. The in teractions between parity and time of feeding and between parity and diet on DMI were not significant. The proportions of the daily feed intake consumed within 3 -h intervals relative to feeding are given in Table 4 . Across these intervals, hour after feeding $(P=0.001)$ and the interaction between hour after feeding and time of feeding $(P=0.001)$ affected these proportions. Parity, the interaction between diet and parity, and the interaction between parity and time of feeding did not affect these proportions across any of these intervals. Across diets and parities, changing the time of feed delivery from 0900 to $2100 \mathrm{~h}$ increased the proportion of daily feed intake consumed within $3 \mathrm{~h}$ after feeding from 26.2 to $37.1 \%(P=0.001)$. However, the proportion of feed consumed between 3 and $6 \mathrm{~h}$ after feeding was lower $(P=0.001)$ for $2100 \mathrm{~h}$-fed than for $0900 \mathrm{~h}$-fed cows. As a result, the proportion of the feed consumed within $6 \mathrm{~h}$ after feeding did not differ between these times of feed delivery.

The percentage of ort particles longer than $8 \mathrm{~mm}$ was affected by diet and by time of feeding (Table 3). This diet effect was expected, because the LC diet contained more coarse fiber than the HC diet (Table 1). The proportion of coarse feed particles in the orts of the cows fed at $2100 \mathrm{~h}$ was less $(P=0.01)$ than that in the orts of cows fed at $0900 \mathrm{~h}$, which suggests that the cows fed at $2100 \mathrm{~h}$ selected less against coarse feed particles. 
Table 4. Effects of diet composition, time of feed delivery (TF, 0900 or $2100 \mathrm{~h}$ ), and parity [primiparous (1) or multiparous ( $\geq 2)$ ] on proportions of daily matter intake consumed within a 3 -h period relative to feed delivery of dairy cows

\begin{tabular}{|c|c|c|c|c|c|c|c|c|c|c|c|c|c|c|c|}
\hline \multirow{2}{*}{$\begin{array}{l}\text { Hour after } \\
\text { feeding, h }\end{array}$} & \multicolumn{4}{|c|}{$\mathrm{HC} \operatorname{diet}^{1}$} & \multicolumn{4}{|c|}{ LC $\operatorname{diet}^{1}$} & \multirow{2}{*}{$\mathrm{SE}$} & \multirow{2}{*}{\multicolumn{6}{|c|}{ Effects, $P$-value }} \\
\hline & \multicolumn{2}{|c|}{$0900 \mathrm{~h}$} & \multicolumn{2}{|c|}{$2100 \mathrm{~h}$} & \multicolumn{2}{|c|}{$0900 \mathrm{~h}$} & \multicolumn{2}{|c|}{$2100 \mathrm{~h}$} & & & & & & & \\
\hline 0 to 3 & 24.0 & 26.7 & 36.7 & 33.8 & 26.0 & 28.0 & 42.1 & 35.6 & 4.33 & 0.33 & 0.001 & 0.57 & 0.64 & 0.69 & 0.18 \\
\hline 3 to 6 & 13.3 & 18.7 & 5.8 & 7.8 & 19.9 & 19.2 & 8.2 & 9.4 & 1.45 & 0.86 & 0.001 & 0.09 & 0.42 & 0.07 & 0.70 \\
\hline 12 to 15 & 6.9 & 10.6 & 7.4 & 6.3 & 7.2 & 6.6 & 8.3 & 8.7 & 1.86 & 0.96 & 0.91 & 0.67 & 0.23 & 0.62 & 0.50 \\
\hline 15 to 18 & 6.3 & 8.0 & 8.6 & 10.4 & 3.7 & 5.0 & 11.9 & 10.4 & 1.67 & 0.64 & 0.001 & 0.52 & 0.10 & 0.56 & 0.59 \\
\hline 18 to 21 & 10.0 & 6.8 & 6.2 & 10.5 & 5.7 & 8.6 & 5.1 & 6.8 & 1.91 & 0.15 & 0.61 & 0.26 & 0.64 & 0.48 & 0.22 \\
\hline 21 to 24 & 1.2 & 4.8 & 8.2 & 7.0 & 2.4 & 2.6 & 6.1 & 5.5 & 2.51 & 0.48 & 0.03 & 0.75 & 0.71 & 0.67 & 0.41 \\
\hline
\end{tabular}

${ }^{1} \mathrm{HC}=$ higher concentrate (forage:concentrate $\left.=38: 62\right) ; \mathrm{LC}=$ lower concentrate $($ forage: concentrate $=51: 49)$.

Aharoni et al. (2005) reported a decline in DMI in response to afternoon and evening feeding instead of morning feeding under hot weather conditions. Unlike the present study, Aharoni et al. (2005) delivered the feed in 4 separate portions for evening-fed cows (i.e., $20 \%$ at $0615 \mathrm{~h}, 30 \%$ at $1530 \mathrm{~h}, 25 \%$ at $1900 \mathrm{~h}$, and $25 \%$ at $2100 \mathrm{~h}$ ). These differences in timing and frequency of feed delivery between our study and the study from Aharoni et al. (2005) may explain why the effect of evening feeding differed between these studies. In agreement with our study, Kennedy et al. (2004) and Small et al. (2004) reported that morning feeding and evening feeding of beef cattle resulted in similar daily DMI.

Eastridge et al. (1998) concluded that the DMI of lactating dairy cows decreases when the temperature exceeds $20^{\circ} \mathrm{C}$. The average daily ambient temperature during the present experiment was $20.4^{\circ} \mathrm{C}$, but temperatures of up to $25^{\circ} \mathrm{C}$ were recorded. Hence, differences in ambient temperature after feed delivery between 0900 $\mathrm{h}$-fed cows and $2100 \mathrm{~h}$-fed cows could have resulted in differences in DMI. However, Eastridge et al. (1998) estimated that the decrease in DMI as a result of an ambient temperature of $25^{\circ} \mathrm{C}$ is only $3 \%$. As a result, differences in ambient temperature at the time of feed delivery cannot fully explain the large differences in feed intake in the $3 \mathrm{~h}$ after feeding between $0900 \mathrm{~h}$-fed cows and $2100 \mathrm{~h}$-fed cows.

In agreement with our study, Haley et al. (2000), and DeVries et al. (2005) also found that fresh feed delivery is a major determinant of diurnal patterns in feed intake of dairy cows. Phillips and Rind (2001) and DeVries et al. (2005) observed that increasing the frequency of feed delivery increases the feed intake during the evening, which suggests that that motivation to eat is elevated during this time. This might explain why in our study the feed consumption within $3 \mathrm{~h}$ of feed delivery was greater in $2100 \mathrm{~h}$-fed compared with 0900 h-fed cows. Lights were turned off at $2230 \mathrm{~h}$ (i.e., at $1 \mathrm{~h}$ and $30 \mathrm{~min}$ after the $2100 \mathrm{~h}$ feed delivery). This would have been anticipated by the cows. Hence, the differences in the hours of light after feed delivery could have caused differences in the feeding behavior after feed delivery of $0900 \mathrm{~h}$ - and $2100 \mathrm{~h}$-fed cows. Due to the light regimen adopted in our study, melatonin would have increased sooner after feed delivery in $2100 \mathrm{~h}$-fed cows than in $0900 \mathrm{~h}$-fed cows (Illnerova and Sumova, 1997). Lima et al. (1998) concluded that the nighttime increase in blood glucose and insulin could, at least in part, be mediated by the nighttime surge in melatonin secretion. Because blood glucose and insulin can affect feed intake (Allen, 2000), the shorter period between feed delivery and the increase of melatonin in 2100 h-fed cows compared with $0900 \mathrm{~h}$-fed cows could have affected the differences in feeding behavior between these 2 groups of cows.

\section{Blood Metabolites}

Glucose. Cows fed the HC diet had greater plasma glucose across sampling times than cows fed the LC diet (Table 5). The interaction between dietary concentrate level and time of feeding tended to be significant $(P=$ 0.08). The effects of time of feeding and parity and the interaction between diet and parity on plasma glucose across sampling times were not significant. The interactions between hour after feeding and diet, between hour after feeding and parity, as well as the 3-way interactions between hour after feeding, diet, time of feeding, and parity did not affect plasma glucose. Hour after feeding affected plasma glucose, and the interaction between time of feeding and hour after feeding on plasma glucose was also significant (Table 6). The increase in plasma glucose starting at $2 \mathrm{~h}$ after feed delivery was larger in cows fed at $2100 \mathrm{~h}$ than in cows 


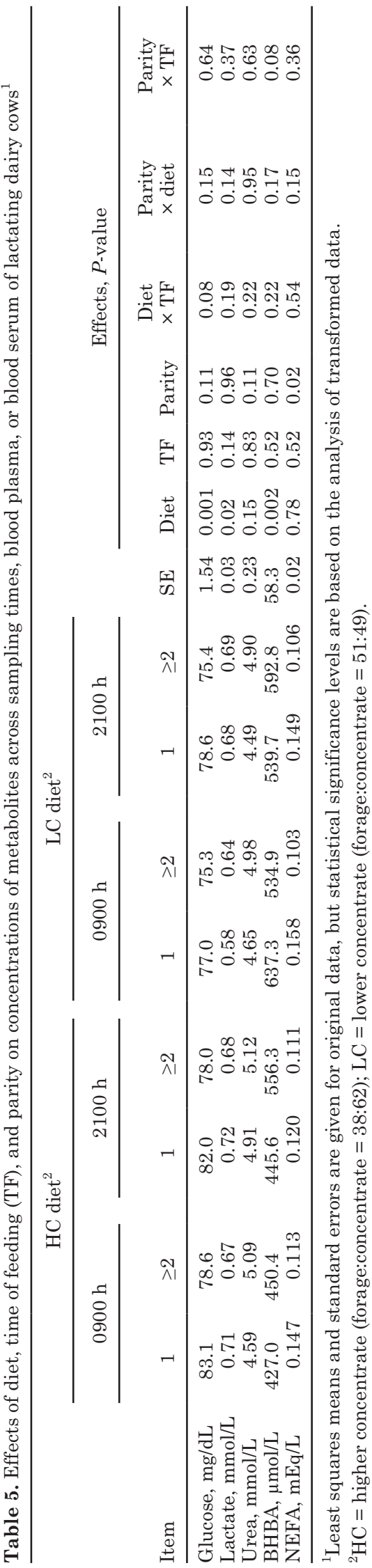

fed at $0900 \mathrm{~h}$ (Figure 1). Plasma glucose level of 2100 $\mathrm{h}$-fed cows decreased to a low at $2 \mathrm{~h}$ after feeding, after which it increased until $6 \mathrm{~h}$ after feeding and remained elevated above prefeeding level until $14 \mathrm{~h}$ after feeding. The plasma glucose level of $0900 \mathrm{~h}$-fed cows did not vary throughout the 24 -h period.

The greater plasma glucose in cows fed the $\mathrm{HC}$ diet compared with those fed the LC diets agrees with earlier studies (Andersen et al., 2004). The postfeeding decline in plasma glucose agrees with several other studies (Sutton et al., 1988; Oba and Allen, 2003a,b; Plaizier et al., 2005). This postfeeding decline in blood glucose may be attributed to an increase in blood insulin due to an increase in propionate availability (Sutton et al., 1988; Blum et al., 2000; Oba and Allen, 2003a,b) and an insulin-driven increase in glucose utilization by the periphery (Brockman, 1978). The greater amount of feed consumed within $3 \mathrm{~h}$ after feed delivery in 2100 h-fed cows than in 0900 h-fed cows (Table 4), which would have resulted in greater rumen fermentation and greater propionate availability after feed delivery, could explain the greater increase in plasma glucose starting at $2 \mathrm{~h}$ after feed delivery in evening-fed cows. The steadier eating pattern of $0900 \mathrm{~h}$-fed cows could have been the cause for the lower diurnal fluctuation in blood glucose in these cows.

Lactate. Cows fed the $\mathrm{HC}$ diet had greater $(P=$ 0.02) plasma lactate across sampling times than cows

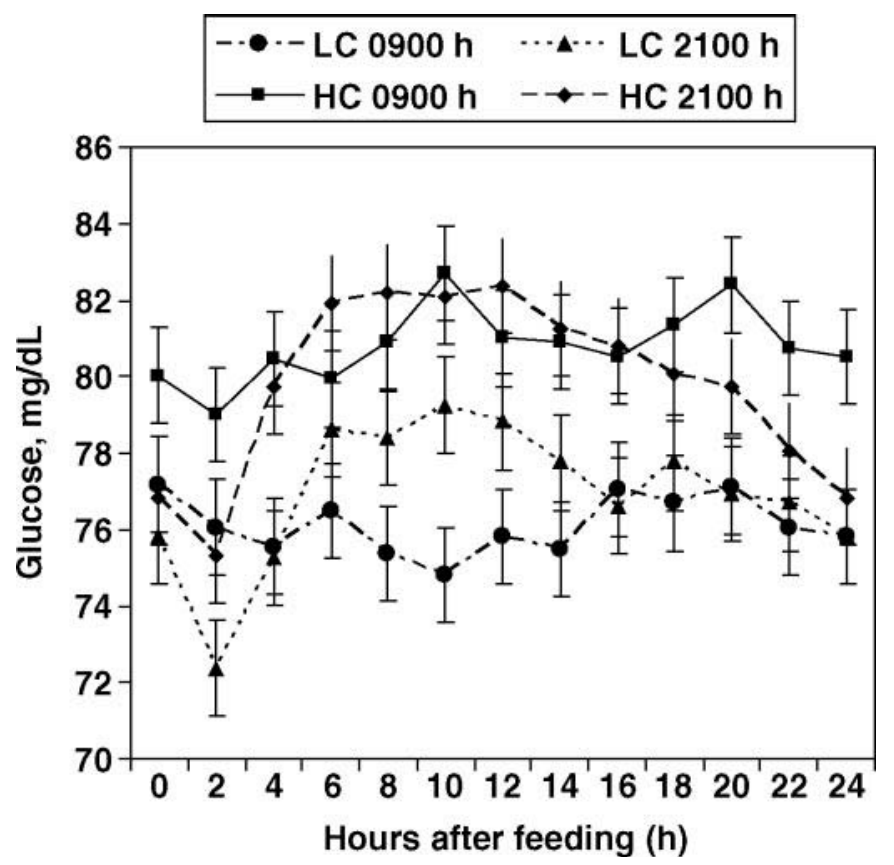

Figure 1. Postfeeding patterns of plasma glucose in primiparous and multiparous cows fed a higher concentrate (HC) or a lower concentrate diet (LC) at 0900 or $2100 \mathrm{~h}$. 
fed the LC diet (Table 5). The effects of time of feeding and parity and the interactions between dietary concentrate level, time of feeding, and parity on plasma glucose across sampling times were not significant. Hour after feed delivery affected plasma lactate (Table 6). The interaction between time of feeding and hour after feed delivery on plasma lactate was also significant, because plasma lactate showed a 50\% increase at 2 to $4 \mathrm{~h}$ after feeding in $2100 \mathrm{~h}$-fed cows (Figure 2). However, no significant increase in $0900 \mathrm{~h}$-fed cows was found when compared with prandial baselines. Plasma lactate increased more after feed delivery in $2100 \mathrm{~h}$-fed cows than in $0900 \mathrm{~h}$-fed cows. The interactions between hour after feeding and concentrate level, between hour after feeding and parity, and the 3-way interactions between hour after feeding, diet, time of feeding, and parity did not affect plasma lactate.

The greater starch supply by the HC diet compared with the LC diet would have led to greater propionate in the rumen (Khorasani, and Kennelly, 2001). This greater rumen propionate may have, in turn, increased the lactate delivery to the liver (Giesecke and Stangassinger, 1980; Baldwin and McLeod, 2000; Reynolds, 2002). Likewise, Huntington et al. (1996) found that feeding steers a higher concentrate diet resulted in net splanchnic release of lactate but that a lower concentrate diet was associated with net uptake of lactate. The larger increase in plasma lactate after the feed delivery at $2100 \mathrm{~h}$ compared with the feed delivery at $0900 \mathrm{~h}$ may be related to the greater feed intake during the $3 \mathrm{~h}$ after the 2100-h feed delivery. This increase in feed intake would have increased postprandial rumen fermentation, which would have increased propionate availability, lactate production, and lactate delivery to the liver (Baldwin and McLeod, 2000; Reynolds, 2002; Lemosquet et al., 2004). Because the hepatic uptake of lactate is lower than that of propionate (Armentano, 1992), the increases in portal lactate can be expected to elevate the circulating blood lactate. A parallel study showed that $2100 \mathrm{~h}$-fed cows had greater blood insulin at $2 \mathrm{~h}$ after feed delivery than $0900 \mathrm{~h}$-fed cows (Furedi et al., 2006). This could also have affected the postprandial variation in blood lactate, because insulin tends to reduce hepatic metabolism of lactate in favor of its greater peripheral availability (Brockman, 1985).

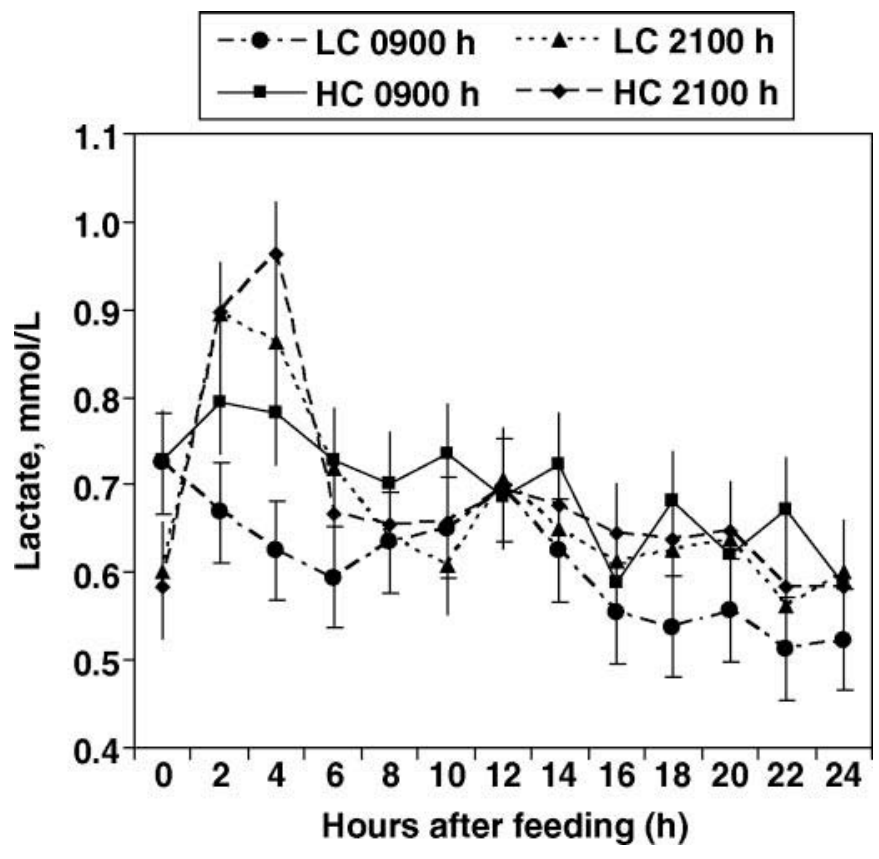

Figure 2. Postfeeding patterns of plasma lactate in primiparous and multiparous cows fed a higher concentrate (HC) or a lower concentrate diet (LC) at 0900 or $2100 \mathrm{~h}$.

Urea. Dietary concentrate level, time of feeding, and parity, as well as their interactions, did not affect plasma urea across sampling times (Table 5). The interactions between hour after feeding and time of feeding, between hour after feeding and parity, and the 3-way interactions between hour after feeding, concentrate level, time of feeding, and parity on plasma urea were not significant. The effects of hour after feeding and the interaction between hour after feeding and concentrate level on plasma urea were significant (Table 6). This was mainly due to the different 24 -h variation in plasma urea of the cows on the HC diet fed at $2100 \mathrm{~h}$, compared with the other cows (Figure 3). In all cows on the LC diet, and in the cows fed the HC diet at $0900 \mathrm{~h}$, plasma urea increased until 2 to $4 \mathrm{~h}$ after feeding and subsequently deceased, only to start rising again at 16 to $18 \mathrm{~h}$ after feed delivery. In contrast, the greatest level of plasma urea in the cows fed the $\mathrm{HC}$ diet fed at $2100 \mathrm{~h}$ occurred at $14 \mathrm{~h}$ after feeding.

Table 6. Effects of hour after feeding (HFD) and the interactions of HFD with diet (DT), time of feeding (TF), and parity (PAR) on metabolites in blood plasma or blood serum of lactating dairy cows

\begin{tabular}{lccccccc}
\hline Item & HFD & HFD $\times$ DT & HFD $\times$ TF & HFD $\times$ PAR & HDF $\times$ DT $\times$ TF & HFD $\times$ DT $\times$ PAR & HFD $\times$ TF $\times$ PAR \\
\hline Glucose, mg/dL & $<0.001$ & 0.31 & $<0.001$ & 0.18 & 0.49 & 0.74 & 0.14 \\
Lactate, mmol/L & $<0.001$ & 0.56 & $<0.001$ & 0.18 & 0.37 & 0.63 & 0.82 \\
Urea, mmol/L & $<0.001$ & $<0.001$ & 0.17 & 0.22 & 0.21 & 0.01 & 0.55 \\
BHBA, $\mu \mathrm{mol} / \mathrm{L}$ & $<0.001$ & 0.17 & $<0.001$ & 0.63 & 0.68 & 0.83 & 0.15 \\
NEFA, $\mathrm{mEq} / \mathrm{L}$ & 0.04 & 0.05 & 0.13 & 0.01 & & \\
\hline
\end{tabular}




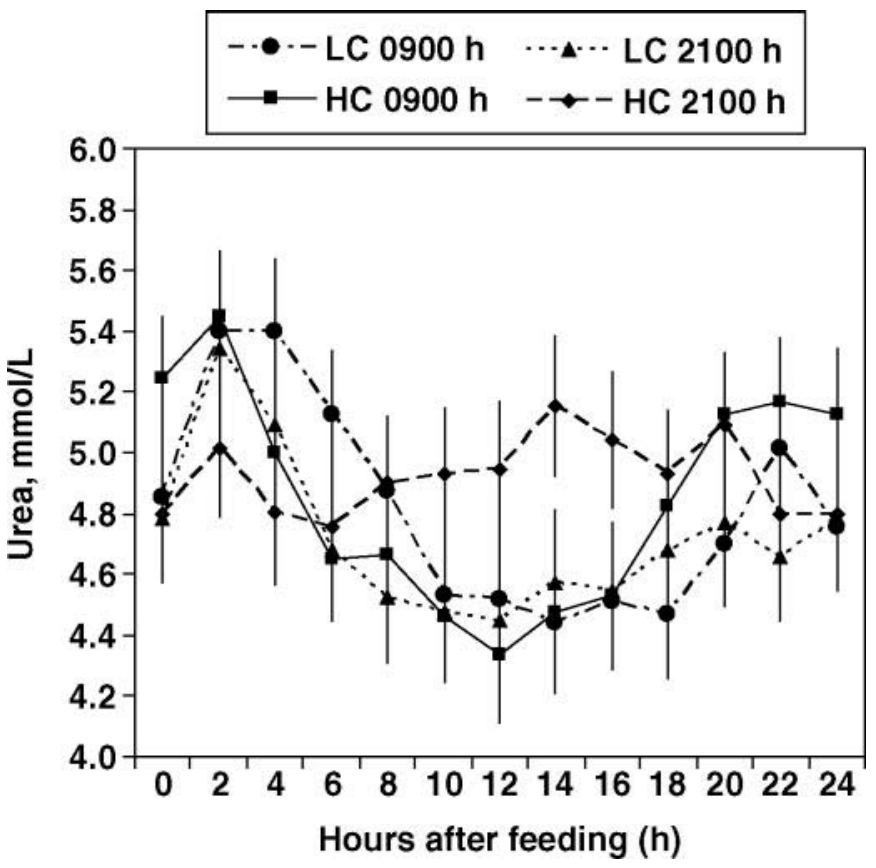

Figure 3. Postfeeding patterns of plasma urea in primiparous and multiparous cows fed a higher concentrate (HC) or a lower concentrate diet (LC) at 0900 or $2100 \mathrm{~h}$.

Postfeeding increases in blood urea of lactating cows have also been shown by other studies and are related to the increases in rumen ammonia due to rumen fermentation (Gustafsson and Palmquist, 1993; Blum et al., 2000; Plaizier et al., 2005). Despite the greater feed and $\mathrm{N}$ intake within $3 \mathrm{~h}$ of feeding in $2100 \mathrm{~h}$-fed compared with $0900 \mathrm{~h}$-fed cows, the postprandial plasma urea increase and milk protein yield were comparable between the 2 feeding times. Hence, the greater $\mathrm{N}$ intake within $3 \mathrm{~h}$ of feeding may not have oversupplied $\mathrm{N}$ to the rumen microbes in $2100 \mathrm{~h}$-fed cows.

$\boldsymbol{B H B A}$. The HC diet resulted in lower plasma BHBA across sampling times compared with the LC diet (Table 5). The effects of time of feeding, parity, and the interactions between dietary concentrate level and time of feeding and between parity and concentrate level on plasma BHBA across sampling times were not significant. However, the interaction between time of feeding and parity tended to affect $(P=0.08)$ plasma BHBA across sampling times. Hour after feeding, the interaction between hour after feeding and time of feeding, and the 3 -way interaction between hour after feeding, concentrate level, and parity affected plasma BHBA (Table 6). As a result, the relationships between concentrate level, time of feed delivery, and hour after feeding were plotted by parity (Figure 4). The interactions between hour after feeding and time of feeding, and between hour after feeding and parity, as well as
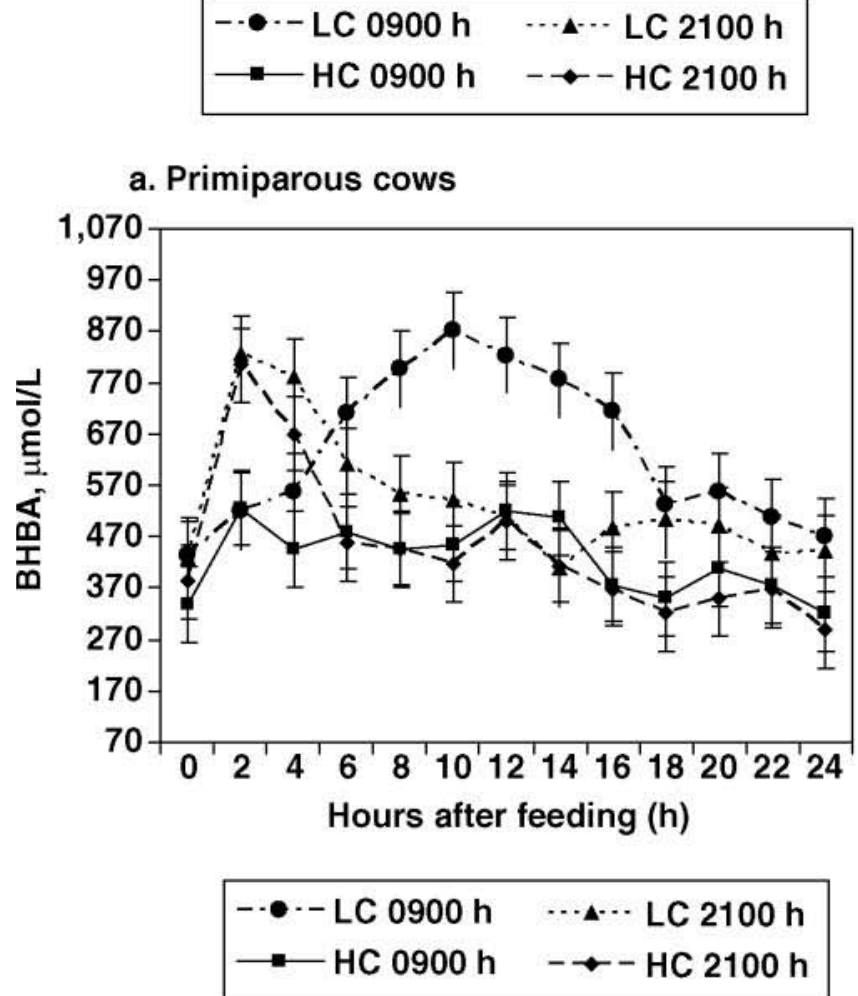

\section{b. Multiparous cows}

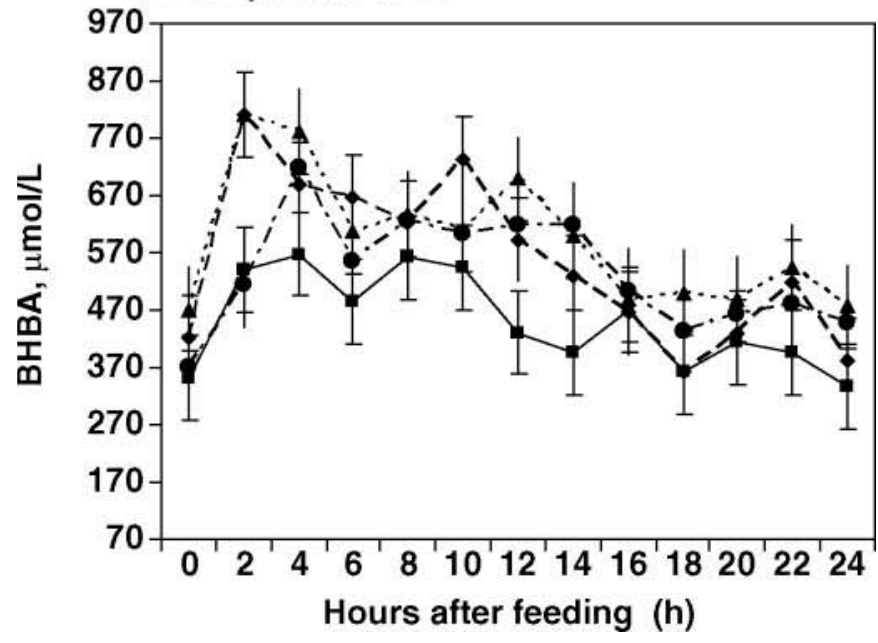

Figure 4. Postfeeding patterns of plasma BHBA in (a) primiparous cows and (b) multiparous cows fed a higher concentrate (HC) or a lower concentrate diet (LC) at 0900 or $2100 \mathrm{~h}$.

the 3-way interaction between hour after feeding, diet, and time of feeding on plasma BHBA, were not significant. The effects of the 3-way interaction between hour after feeding, diet, and parity and the 3-way interaction between hour after feeding, time of feeding, and parity on plasma BHBA were significant. Feed delivery at $2100 \mathrm{~h}$ increased plasma BHBA 2-fold at 


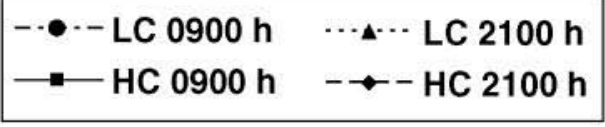

a. Primiparous cows
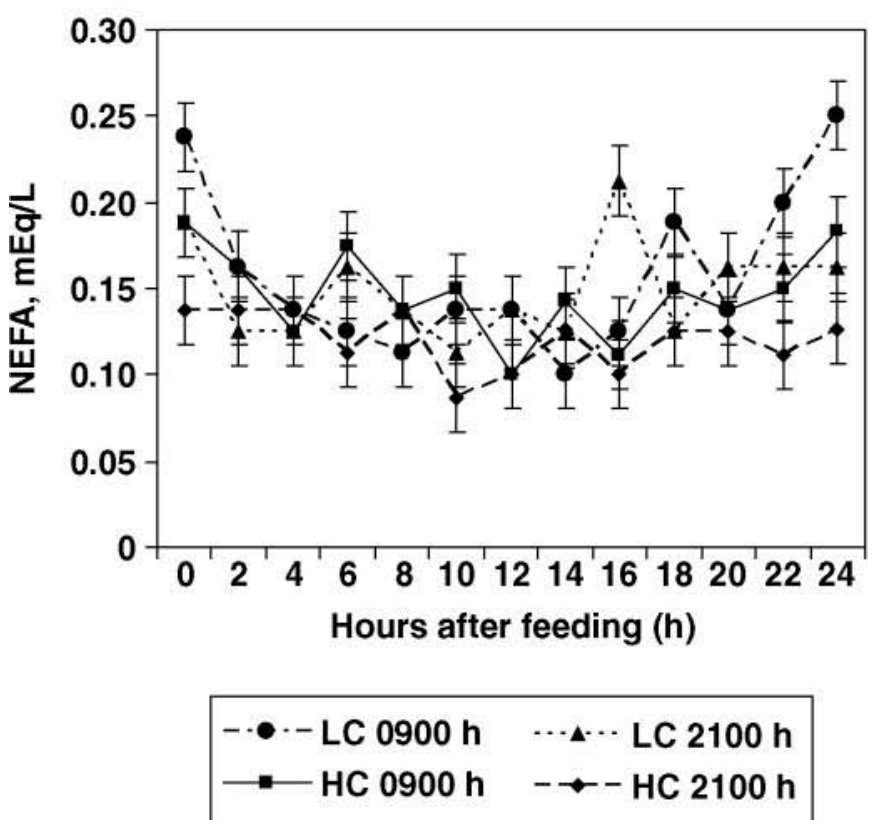

\section{b. Multiparous cows}

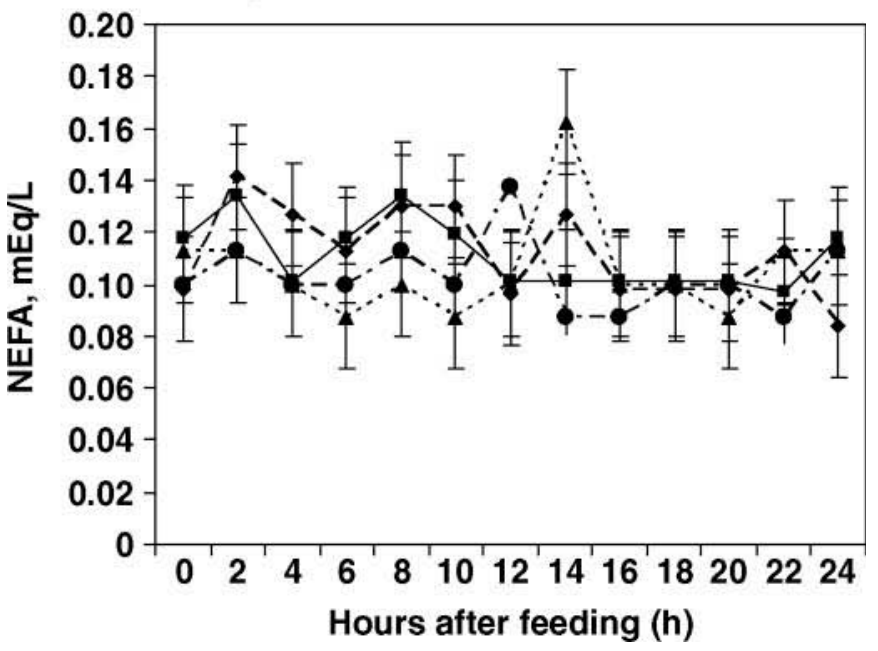

Figure 5. Postfeeding patterns of plasma NEFA in (a) primiparous cows and (b) multiparous cows fed a higher concentrate (HC) or a lower concentrate diet (LC) at 0900 or $2100 \mathrm{~h}$.

$2 \mathrm{~h}$ postfeeding, followed by a rapid decline until $6 \mathrm{~h}$ postfeeding (Figure 4). However, in $0900 \mathrm{~h}$-fed cows, plasma BHBA at $2 \mathrm{~h}$ postfeeding rose less than $50 \%$ compared with the preprandial level. Plasma BHBA in $0900 \mathrm{~h}$-fed cows remained at peak until $10 \mathrm{~h}$ after feed delivery when it declined.
The significance of the interactions between hour after feeding, dietary concentrate level and parity, and between hour after feeding, time of feeding, and parity were mainly due to the increase in plasma BHBA in primiparous cows fed the LC diet at $0900 \mathrm{~h}$. This increase was slower and longer than that in the primiparous cows fed the low-concentrate diet at $2100 \mathrm{~h}$, in the primiparous cows fed the high-concentrate diet, and in the multiparous cows. The reason for this is unclear but might be related to the lower feed intake in the first $3 \mathrm{~h}$ after feeding and, subsequently, lower rumen fermentation in primiparous cows fed the lowconcentrate diets compared with all other groups of cows.

The lower plasma BHBA in cows fed the HC diet agrees with earlier studies (Andersen et al., 2004) and may be explained by the greater blood glucose of the cows on the HC diet, which would have increased insulin and reduced fatty acid mobilization (Lean et al., 1992). Similar to our study, an immediate postprandial increase in plasma BHBA has also been observed in twice-daily-fed lactating cows (de Boer et al., 1985; Sutton et al., 1988;Blum et al., 2000). In our study, $2100 \mathrm{~h}$-fed cows consumed a greater amount of feed within $3 \mathrm{~h}$ of feed delivery than $0900 \mathrm{~h}$-fed cows (Table 4). The greater feed intake after feeding in $2100 \mathrm{~h}$-fed cows would have resulted in greater rumen butyrate shortly after feed delivery. This greater butyrate availability will have increased butyrate transformation to BHBA across the rumen wall (Reynolds, 2002), thereby elevating BHBA appearance in portal and peripheral blood.

NEFA. The average daily levels of plasma NEFA were not affected by dietary concentrate level, time of feeding, and their interaction (Table 5). Multiparous cows had lower $(P=0.02)$ plasma NEFA across sampling times than primiparous cows. The interactions between parity and time of feeding and between parity and concentrate level on plasma NEFA were not significant. Hour after feeding $(P=0.04)$ and the interactions between hour after feeding and dietary concentrate level $(P=0.05)$ and the interaction between hour after feeding and parity $(P=0.01)$ on plasma NEFA were significant (Table 6 ). The within-24-h variation in plasma NEFA was much greater in primiparous cows than in multiparous cows, and, as a result, this variation was plotted by parity (Figure 5). In primiparous cows, plasma NEFA decreased after feed delivery and started to increase at 16 to $18 \mathrm{~h}$ after feed delivery. This decline and subsequent increase was not observed in multiparous cows.

The difference in diurnal variation in NEFA between multiparous cows and primiparous cows might be related to the greater plasma NEFA in primiparous 
cows. This difference between parities could be due to the greater energy needs for growth of the primiparous cows combined with their energy requirements for milk production and their lower feed intake compared with multiparous cows (Rémond et al., 1991). The increase in plasma NEFA after midnight in $0900 \mathrm{~h}$-fed primiparous cows agrees with several other studies (Sutton et al., 1988; Blum et al., 2000; Plaizier et al., 2005). The increase in plasma NEFA starting at 16 to $18 \mathrm{~h}$ after feed delivery in primiparous cows may be explained by the lower feed intake resulting in lower nutrient availability during this period (Table 4). This would have lowered plasma insulin and, as a result, increased lipolysis and blood NEFA (Brockman, 1978; Sutton et al., 1988). Comparable to the postprandial decline lasting for $4 \mathrm{~h}$ in $0900 \mathrm{~h}$-fed primiparous cows, plasma NEFA in 2100 h-fed primiparous cows showed a tendency for a reduction in NEFA for only $2 \mathrm{~h}$ postfeeding (Figure 5). The $2100 \mathrm{~h}$-fed primiparous cows exhibited another decrease in plasma NEFA at $10 \mathrm{~h}$ postfeeding, which was not observed in $0900 \mathrm{~h}$-fed primiparous cows. The decline in plasma NEFA after feed delivery may be attributed to the increase in insulin after this delivery (Brockman, 1978; Sutton et al., 1988; Furedi et al., 2006). The greater plasma insulin of $2100 \mathrm{~h}$-fed than of $0900 \mathrm{~h}$-fed primiparous cows at 6 to $8 \mathrm{~h}$ after feeding (Furedi et al., 2006) may have contributed to lower NEFA at $10 \mathrm{~h}$ postfeeding in $2100 \mathrm{~h}$-fed cows.

A lack of diet effect on average blood NEFA has also been reported by others (Sutton et al., 1988; Nielsen et al., 2003; Andersen et al., 2004). However, Nielsen et al. (2003) found that blood NEFA rose at $3 \mathrm{~h}$ before morning feeding, particularly for cows on a high-concentrate diet. In that study, the peak in plasma NEFA occurred at feeding time (1000 h) and was attributed to the lower energy availability in the hours before feeding. Similarly, in our study, plasma NEFA in 0900 h-fed cows peaked at $0900 \mathrm{~h}$ (i.e., at feed delivery time) and declined significantly by $4 \mathrm{~h}$ after feed delivery.

None of the plasma samples collected during our study had a NEFA concentration greater than 0.3 $\mathrm{mEq} / \mathrm{L}$, which is when the mammary gland starts to directly take up the circulating NEFA for milk fat secretion (Nielsen et al., 2003). The NEFA levels obtained in the current trial were close to the lower end of normal range expected in bovine plasma ( 0.1 to 0.37 $\mathrm{mEq} / \mathrm{L})$. Thus, little effect of the diurnal patterns in plasma NEFA on milk fat was expected.

\section{Milk Production and Composition}

Feeding the HC diet instead of the LC diet did not affect milk yield, decreased milk fat percentage $(P=0.001)$ and milk fat yield, increased milk protein percentage
$(P=0.001)$, and tended to increase milk protein yield $(P=0.06$; Table 3$)$. Time of feed delivery did not affect milk yield and milk protein. Feeding at $2100 \mathrm{~h}$, instead of at $0900 \mathrm{~h}$, increased milk fat percentage and milk fat yield in multiparous cows but not in primiparous cows. Parity did not affect milk yield and milk composition. The interaction of diet and parity on milk yield and milk composition was not significant. The effects of the interactions between parity and dietary concentrate level and between parity and time of feeding on milk protein percentage were significant, because the effects of dietary concentrate level and feeding time were greater in primiparous cows than in multiparous cows. The interactions between milking time and diet and between milking time and time of feeding on milk yield and milk composition were all not significant.

The lower milk fat and greater milk protein of cows fed the HC diet were expected (Khorasani and Kennelly, 2001). The reason for the greater milk fat of multiparous cows fed at $2100 \mathrm{~h}$ compared with those fed at $0900 \mathrm{~h}$ is not clear, because several factors could have contributed to this difference. Feed intake was greater in the $3 \mathrm{~h}$ after feed delivery, and blood concentrations of lactate and BHBA were greater at 2 and $4 \mathrm{~h}$ after feed delivery in $2100 \mathrm{~h}$-fed cows than in 0900 $\mathrm{h}$-fed cows. This suggests greater rumen fermentation and a greater availability of acetate and BHBA for milk fat synthesis in the fist hours after feed delivery in the evening-fed cows. The $2100 \mathrm{~h}$-fed multiparous cows consumed more long feed particles than 0900 h-fed multiparous cows. This could have resulted in a lower rumen $\mathrm{pH}$ (Mertens, 1997) and, as a result, in lower milk fat (Griinari et al., 1998) in the $0900 \mathrm{~h}$-fed multiparous cows. In contrast, the ort particle size distribution as well as milk fat did not differ between $2100 \mathrm{~h}$-fed and $0900 \mathrm{~h}$-fed primiparous cows. Furedi et al. (2007) observed that the insulin resistance of peripheral tissues at 3 and $10 \mathrm{~h}$ after feed delivery was greater in $2100 \mathrm{~h}$-fed cows than in $0900 \mathrm{~h}$-fed cows. This could have resulted in a greater nutrient supply to the mammary gland of $2100 \mathrm{~h}$-fed cows compared with the $0900 \mathrm{~h}$-fed cows at these times and could have contributed to the greater milk fat in evening-fed multiparous cows (Bauman and Griinari, 2003).

The low milk fat percentages and the inversion of the milk fat percentage and milk protein percentage of both diets suggest that subacute ruminal acidosis (SARA; Kleen et al., 2003) occurred. It cannot be excluded that the effects of concentrate level and time of feeding on milk fat would have been greater if milk fat production had been greater. The occurrence of SARA might be explained by the low dietary NDF content of the diets, which was $28.6 \%$ of $\mathrm{DM}$ and $33.8 \%$ of $\mathrm{DM}$ for the $\mathrm{HC}$ diet and the LC diet, respectively. It has been 
suggested that barley grain-based diets need to contain at least $34 \%$ of DM to prevent SARA (Beauchemin, 1991). Even if diets contain sufficient NDF, then sorting against long feed particles can put cows at risk of SARA (Bhandari et al., 2007). This shows that cows on both diets were at risk of SARA.

\section{CONCLUSIONS}

Feed delivery at $2100 \mathrm{~h}$ instead of $0900 \mathrm{~h}$ increased feed intake within $3 \mathrm{~h}$ after feeding, without affecting daily DMI, milk yield, and milk protein in cows that did not experience heat stress. This change in the time of feed delivery increased milk fat in multiparous cows but not in primiparous cows. The increased feed intake after feeding increased altered diurnal patterns of blood metabolites. The interaction between dietary concentrate level and time of feed delivery on daily feed intake and milk production was not significant. The mechanism responsible for the greater milk fat in 2100 h-fed multiparous cows is not clear. However, differences in sorting and the intake of coarse feed particles, availability precursors for milk fat synthesis, and diurnal variation in glucose tolerance could play a role in this mechanism. Results suggest that in the absence of heat stress, evening feed delivery can benefit lactating cows but that parity can mediate cow response to feed delivery time.

\section{ACKNOWLEDGMENTS}

The staff of the Glenlea Research Station, and Terri Garner and Janice Haines of the Department of Animal Science, University of Manitoba, are thanked for their technical assistance. This study was supported by grants from Dairy Farmers of Canada (Montreal, Quebec, Canada), the Agri-Food Development Research Initiative (Morris, Manitoba, Canada), and the Natural Sciences and Engineering Research Council of Canada (Ottawa, Ontario, Canada). Akbar Nikkhah was the recipient of a national scholarship from the Ministry of Science, Research, and Technology in Iran.

\section{REFERENCES}

Aharoni, Y., A. Brosh, and Y. Harari. 2005. Night feeding for highyielding dairy cows in hot weather: Effects on intake, milk yield and energy expenditure. Livest. Prod. Sci. 92:207-219.

Allen, M. S. 2000. Effects of diet on short-term regulation of feed intake by lactating dairy cattle. J. Dairy Sci. 83:1598-1624.

Andersen, J. B., N. C. Friggens, T. Larsen, M. Vestergaard, and K. L. Ingvartsen. 2004. Effect of energy density in the diet and milking frequency on plasma metabolites and hormones in early lactation dairy cows. J. Vet. Med. 51:52-57.

AOAC. 1990. Official Methods of Analysis. 15th ed. AOAC Int., Arlington, VA.
Armentano, L. E. 1992. Ruminant hepatic metabolism of volatile fatty acids, lactate and pyruvate. J. Nutr. 122:838-842.

Baldwin, R. L., and K. R. McLeod. 2000. Effects of diet forage:concentrate ratio and metabolizable energy intake on isolated rumen epithelial cell metabolism in vitro. J. Anim. Sci. 78:771-783.

Bauman, D. E., and J. M. Griinari. 2003. Nutritional regulation of milk fat synthesis. Annu. Rev. Nutr. 23:203-227.

Beauchemin, K. A. 1991. Effects of dietary neutral detergent fibre concentration and alfalfa hay quality on chewing, rumen function, and milk production of dairy cows. J. Dairy Sci. 74:3140-3151.

Bhandari, S. K., K. H. Ominski, K. M. Wittenberg, and J. C. Plaizier. 2007. Effects of chop length of alfalfa and corn silage on milk production and rumen fermentation of dairy cows. J. Dairy Sci. 90:2355-2366.

Blum, J. W., R. M. Bruckmaier, P. Y. Vacher, A. Munger, and F. Jans. 2000. Twenty-four-hour patterns of hormones and metabolites in week 9 and 19 of lactation in high-yielding dairy cows fed triglycerides and free fatty acids. J. Vet. Med. A Physiol. Pathol. Clin. Med. 47:43-60.

Brockman, R. P. 1978. Roles of glucagons and insulin in the regulation of metabolism in ruminants: A review. Can. Vet. J. 19:55-62.

Brockman, R. P. 1985. Role of insulin in regulating hepatic gluconeogenesis in sheep. Can. J. Physiol. Pharmacol. 63:14601464.

CCAC. 1993. Guide to the Care and Use of Experimental Animals. Vol. 1. E. D. Olfert, B. M. Cross, and A. A. McWilliam, ed. Canadian Council on Animal Care, Ottawa, Ontario, Canada.

de Boer, G., A. Trenkle, and J. W. Young. 1985. Glucagon, insulin, growth hormone, and some blood metabolites during energy restriction ketonemia of lactating cows. J. Dairy Sci. 68:326337.

DeVries, T. J., M. A. G. von Keyserlingk, and K. A. Beauchemin. 2003. Short communication: Diurnal feeding pattern of lactating dairy cows. J. Dairy Sci. 86:4079-4082.

DeVries, T. J., M. A. G. von Keyserlingk, and K. A. Beauchemin. 2005. Frequency of feed delivery affects the behavior of lactating dairy cows. J. Dairy Sci. 88:3553-3562.

Eastridge, M. L., H. F. Bucholtz, A. L. Slater, and C. S. Hall. 1998. Nutrient requirements for dairy cattle of the National Research Council versus some commonly used ration software. J. Dairy Sci. 11:3049-3062.

Furedi, C., A. D. Kennedy, A. Nikkhah, and J. C. Plaizier. 2008 Twenty-four hour plasma glucose and insulin profiles and glucose tolerance in dairy cows fed at $0900 \mathrm{~h}$ or $2100 \mathrm{~h}$. Can. J. Anim. Sci. 88:149. (Abstr.)

Furedi, C., A. D. Kennedy, A. Nikkhah, and J. C. Plaizier. 2006. Glucose tolerance and diurnal variation of circulating insulin in evening and morning fed lactating cows. Adv. Dairy Technol. 18:356. (Abstr.)

Giesecke, D., and M. Stangassinger. 1980. Lactic acid metabolism. Pages 523-539 in Digestive Physiology and Metabolism in Ruminants. Y. Ruckebush and P. Thivend, ed. AVI Publishing, Westport, CT.

Griinari, J. M., D. A. Dwyer, M. A. McGuire, D. E. Bauman, D. L. Palmquist, and K. V. Nurmela. 1998. Trans-octadecenoic acids and milk fat depression in lactating dairy cows. J. Dairy Sci. $81: 1251-1261$.

Gustafsson, A. H., and D. L. Palmquist. 1993. Diurnal variation of rumen ammonia, serum urea, and milk urea in dairy cows at high and low yields. J. Dairy Sci. 76:475-484.

Haley, D. B., J. Rushen, and A. M. de Passille. 2000. Behavioral indicators of cow comfort: Activity and resting behaviour of dairy cows housed in two types of housing. Can. J. Anim. Sci. 80:257263.

Huntington, G. B., E. J. Zetina, J. M. Whitt, and W. Potts. 1996. Effects of dietary concentrate level on nutrient absorption, liver metabolism, and urea kinetics of beef steers fed isonitrogenous and isoenergetic diets. J. Anim. Sci. 74:908-916. 
Illnerova, H., and A. Sumova. 1997. Photic entrainment of the mammalian rhythm in melatonin production. J. Biol. Rhythms 12:547-555

Kennedy, A. D., R. D. Bergen, T. J. Lawson, J. A. Small, and D. M. Veira. 2004. Effects of evening feeding and extended photoperiod on growth, feed efficiency, live animal carcass traits and plasma prolactin of beef heifers housed outdoors during two Manitoba winters. Can. J. Anim. Sci. 84:491-500.

Khorasani, G. R., and J. J. Kennelly. 2001. Influence of carbohydrate source and buffer on rumen fermentation characteristics, milk yield, and milk composition in late-lactation Holstein cows. J. Dairy Sci. 84:1707-1716.

Kleen, J. L., G. A. Hooijer, J. Rehage, and J. P. Noordhuizen. 2003. Subacute ruminal acidosis (SARA): A review. J. Vet. Med. A Physiol. Pathol. Clin. Med. 50:406-414.

Kononoff, P. J., A. J. Heinrichs, and D. R. Buckmaster. 2003. Modification of the Penn State forage and total mixed ration particle separator and the effects of moisture content on its measurements. J. Dairy Sci. 86:1858-1863.

Lean, I. J., M. Bruss, R. L. Baldwin, and H. F. Troutt. 1992. Bovine ketosis: A review. II. Biochemistry and prevention. Vet. Bull. $62: 1-14$.

Lemosquet, S., S. Rigout, A. Bach, H. Rulquin, and J. W. Blum. 2004. Glucose metabolism in lactating cows in response to isoenergetic infusions of propionic acid or duodenal glucose. J. Dairy Sci. 87:1767-1777.

Lima, F. B., U. F. Machado, I. Bartol, P. M. Seraphim, D. H. Sumida, S. M. Moraes, N. S. Hell, M. M. Okamoto, M. J. Saad, C. R. Carvalho, and J. Cipolla-Neto. 1998. Pinealectomy causes glucose intolerance and decreases adipose cell responsiveness to insulin in rats. Am. J. Physiol. 275:E934-E941.

Mertens, D. R. 1997. Creating a system for meeting the fiber requirements of dairy cows. J. Dairy Sci. 80:1463-1481.

Nielsen, N. I., K. L. Ingvartsen, and T. Larsen. 2003. Diurnal variation and the effect of feed restriction on plasma and milk metabolites in TMR-fed dairy cows. J. Vet. Med. A Physiol. Pathol. Clin. Med. 50:88-97.

Oba, M., and M. S. Allen. 2003a. Effects of corn grain conservation method on feeding behavior and productivity of lactating dairy cows at two dietary starch concentrations. J. Dairy Sci. 86:174183.
Oba, M., and M. S. Allen. 2003b. Dose-response effects of intrauminal infusion of propionate on feeding behavior . J. Dairy Sci. 86:2922_2931.

Phillips, C. J., and M. I. Rind. 2001. The effects of frequency of feeding a total mixed ration on the production and behavior of dairy cows. J. Dairy Sci. 84:1979-1987.

Plaizier, J. C., A. M. Fairfield, P. A. Azevedo, A. Nikkhah, T. F Duffield, G. H. Crow, R. Bagg, P. Dick, and B. W. McBride. 2005. Effects of monensin and stage of lactation on variation of blood metabolites within twenty-four hours in dairy cows. J. Dairy Sci. 88:3595-3602.

Rémond, B., M. Cisse, A. Ollier, and Y. Chilliard. 1991. Slow release somatotropin in dairy heifers and cows fed two levels of energy concentrate. J. Dairy Sci. 74:1370-1381.

Reynolds, C. K. 2002. Economics of visceral energy metabolism in ruminants: Toll keeping or internal revenue service? J. Anim. Sci. 80(Suppl. 2):E74-E84.

Robinson, P. H., M. Gill, and J. J. Kennelly. 1997. Influence of time of feeding a protein meal on ruminal fermentation and forestomach digestion in dairy cows. J. Dairy Sci. 80:1366-1373.

Robinson, P. H., M. Gill, and J. J. Kennelly. 2002. Influence of time of feeding a protein meal on diurnal patterns of amino acids in duodenal digesta protein of lactating dairy cows. Anim. Feed Sci. Technol. 97:115-121.

SAS Institute. 2003. SAS/STAT User's Guide. V. 9.1. SAS Institute Inc., Cary, NC.

Sehgal, A. 2004. Molecular Biology of Circadian Rhythms. John Wiley \& Sons Inc., Hoboken, NJ.

Small, J. A., A. D. Kennedy, D. M. Veira, W. P. McCaughey, and D. R. Ward. 2004. Time of feeding and growth promotant effects on the winter growth performance and carcass traits of steers. Can. J. Anim. Sci. 84:133-144.

Sutton, J. D., I. C. Hart, S. V. Morant, E. Schuller, and A. D. Simmonds. 1988. Feeding frequency for lactating cows: Diurnal patterns of hormones and metabolites in peripheral blood in relation to milk-fat concentration. Br. J. Nutr. 60:265-274.

Vasilatos, R., and P. J. Wangsness. 1981. Diurnal variations in plasma insulin and growth hormone associated with two stages of lactation in high producing dairy cows. Endocrinology 108:300-304 